Alima Frida Merani, Bambang lskamto, Yafi Sabila Rosyad "Hubungan Tingkat Pengetahuan dengan Motivasi Pasien Tuberkulosis Paru dalam Menjalani Pengobatan di Puskesmas Umbulharjo 1 Yogyakarta" (hal 64-73)

Received

Revisied

Acceptep

14 Desember 2020

22 Februari 2021

16 Juni 2021

\title{
HUBUNGAN TINGKAT PENGETAHUAN DENGAN MOTIVASI PASIEN TUBERKULOSIS PARU DALAM MENJALANI PENGOBATAN DI PUSKESMAS UMBULHARJO 1 YOGYAKARTA
}

\author{
Alima Frida Merani ${ }^{1}$, Bambang Iskamto ${ }^{2}$, Yafi Sabila Rosyad ${ }^{3 *}$ \\ ${ }^{1}$ Sekolah Tinggi Ilmu Kesehatan Yogyakarta \\ E-mail: Imhanomerani@gmail.com \\ ${ }^{2}$ Sekolah Tinggi Ilmu Kesehatan Yogyakarta \\ E-mail: Iskamto@yahoo.co.id \\ ${ }^{3}$ Sekolah Tinggi Ilmu Kesehatan Yogyakarta \\ E-mail: rosyad2yafi@gmail.com
}

\begin{abstract}
ABSTRAK
Latar Belakang: Motivasi merupakan kekuatan, dorongan, kebutuhan, tekanan dan mekanisme psikologis yang dimaksutkan merupakan akumulasi faktor-faktor internal dan eksternal. Pengetahuan juga mempunyai peran penting pada pasien TB Paru saat menjalani pengobatan TB Paru. Tujuan: Untuk mengetahui hubungan tingkat pengetahuan tentang Tuberkulosis Paru dengan motivasi pasien dalam menjalankan pengobatan di Puskesmas Umbulharjo 1 Yogyakarta. Metode Penelitian: Jenis penelitian ini adalah kuantitatif, metode yang digunakan korelasi dengan pendekatan desain cross sectional. Populasi dalam penelitian ini sebanyak 46 orang dengan sampe 30 responden yang diambil menggunakan teknik purposive sampling. Hasil Penelitian: Hasil uji korelasi Somer's D sebesar .346 dengan nilai $p$ 0,031 lebih besar dari 0,005, artinya ada hubungan signifikan antara tingkat pengetahuan dengan motivasi pasien dalam menjalani pengobatan di Puskesmas Umbulharjo 1 Yogyakarta dengan kekuatan sedang. Kesimpulan: Ada hubungan antara tingkat pengetahuan dengan motivasi pasien dalam menjalani pengobatan di Puskesmas Umbulharjo 1 Yogyakarta.

Kata Kunci: Pengetahuan, Tuberkulosis Paru, motivasi pasien dalam menjalani pengobatan.
\end{abstract}

\begin{abstract}
Background: Motivation is a strength, drive, need, pressure and a psychological mechanism that is forced to be an accumulation of internal and external factors. Knowledge also has an important role in pulmonary TB patients while undergoing pulmonary TB treatment. The Objective: To examine the relationship between the level of knowledge about pulmonary tuberculosis and the motivation of patients to carry out treatment at the Umbulharjo 1 health center in Yogyakarta. The Research Methods: This type of research is quantitative, the method used is correlation with cross sectional design approach. The population in this study were 46 people with up to 30 respondents taken using purposive sampling technique. The Results: Somer's D correlation test results of .346 with $p 0.031$ is more than 0.005 , meaning that there is modereate a significant relationship between the level of knowledge and patient motivation in undergoing treatment at the Umbulharjo 1 Health Center in Yogyakarta. The Conclusion: There is a relationship between the level of knowledge and patient motivation in undergoing treatment at the Umbulharjo 1 Health Center in Yogyakarta.
\end{abstract}

Keywords: Knowledge, a pulmonary tuberculosis, patient motivation in undergoing treatment. 
Jurnal Kesehatan Karya Husada, Vol 9 No 1 Tahun 2021

PISSN 2337649X/EISSN 2655-8874

Alima Frida Merani, Bambang lskamto, Yafi Sabila Rosyad "Hubungan Tingkat Pengetahuan dengan Motivasi

Pasien Tuberkulosis Paru dalam Menjalani Pengobatan di Puskesmas Umbulharjo 1 Yogyakarta" (hal 64-73)

\section{PENDAHULUAN}

Penyakit Tuberkulosis merupakan salah satu dari 10 penyebab kematian tertinggi secara global dan diperkirakan sekitar 10 juta orang yang terjangkit.,. Penyebaran TB paling banyak terjadi di kawasan Asia Tenggara dengan presentase 44\% dari kejadian secara global. Negara dengan kejadian TB terbesar adalah India dengan 27\%, diikuti China sebesar 9\% dan peringkat ketiga diduduki oleh Indonesia sebesar 8\% (WHO, 2018).

Pada tahun 2017 dilaporkan kasus baru TB di Indonessia sebanyak 425 ribu kasus, dengan prevelensi TB di Indonesia sebanyak 391 per 100.000 penduduk serta angka kematian 42 per 100.000 penduduk. Angka kejadian TB pada laki-laki adalah sebesar 245 ribu kasus dan pasien perempuan sebesar 180 ribu kasus. Hasil ini menunjukan bahwa kasus TB pada laki-laki adalah 1,4 kalin lebih besar dibandingkan perempuan. Kasus TB paling banyak terjadi pada kelompok umur 25-34 trahun sebesar 17,2\% diikuti kelompok umur 45-54 tahun sebesar $17,1 \%$ dan selanjutnya pada kelompok umur 25-44 tahun sebesar 16,4\%. Cangkupan kasus TB yang diobati (Case Detection Rate / CDR) pada trahun 2017 adalah sebesar 42,8\% (Kemenkes, 2018).
Salah satu provinsi diindonesia dengan angka TB yang masih tinggi adalah Daerah Istimewa Yogyakarta (DIY). Angka insidendi kematian dan prevelensi TB Paru di Yogyakarta berturut-turut adalah 30,20\%, $32,99 \%$ dan $0,87 \%$ per 100.000 penduduk pertahunn (Profil Dinkes DIY, 2016). Pada 2016 di Kota Yogyakarta ditemukan 1.003 kasus TB Paru, Tiga puskesmas dengan kasus TB terbanyak di Kota Yogyakartas adalah Umbulharjo 1 dengan jumlah kasus sebanyak 59 orang setelah itu diikuti oleh puskesmas Jetis dengan kasus TB sebanyak 47 orang selajutnya puskesmas Mantrijeron 45 orang dan Tegalrejo 45 (Dinkes DIY, 2017)

Menurut penelitian Kozier (2010), Faktor-faktor yang mempengaruhi kepatuhan antaralain motivasi klien untuk sembuh, gaya hidup, persepsi keparahan masalah, keyakinan terhadap penyakit, pengetahuan, penyakit penyerta, efikasi diri, kerumitan, efek samping pengobatan, budaya, kepuasan pasien.

Penelitian Sutarno \& Gilang (2012), tentang faktor-faktor yang mempengaruhi motivasi berobat penderita TBC secara umum ada dua yakni faktor internal dan faktor eksternal sedangka salah faktor internal yang sangat penting adalah tingkat 
Jurnal Kesehatan Karya Husada, Vol 9 No 1 Tahun 2021

PISSN 2337649X/EISSN 2655-8874

Alima Frida Merani, Bambang lskamto, Yafi Sabila Rosyad "Hubungan Tingkat Pengetahuan dengan Motivasi

Pasien Tuberkulosis Paru dalam Menjalani Pengobatan di Puskesmas Umbulharjo 1 Yogyakarta" (hal 64-73)

pengetahuan TB Paru, saat melakukan pengobatan pengetahuan dan dukungan sosial sangatlah diperlukan untuk menunjang kesuskesan pasien TB Paru dalam melanjalani pengobatan. Johansson \& Ginting (2008), dalam penelitiannya menemukan bahwa persepsi positif seseorang tumbuh karena pengetahuan yang baik serta menurut Firdaus, (2009), pengetahuan menjadi faktor penting untuk keberhasilan pengobatan TB.

Dari hasil studi pendahuluan yang dilakukan pada tanggal 15 maret 2019 di Puskesmas Umbulharjo Yogyakarta didapatkan jumlah penderita Tuberkulosis Paru sebanyak 46 orang. Menurut salah satu perawat yang menanggani kasus $\mathrm{TB}$ di Puskesmas Umbulharjo bahwa setiap bulannya ada pasien yang terdiagnosa TB. Setelah dilakukan wawancara dengan 10 responden pasien Tuberkulosis paru didapatkan bahwa 7 responden kurang mengetahui apa itu TBC Paru, cara penularannya dan bagaimana mencegah TBC Paru dan 3 diantaranya dapat menjelaskan apa itu TBC Paru, cara penularannya dan bagaimana mencegahnya, untuk motivasi responden saat menjalani pengobatan TBC Paru selama di Puskesmas Umbulharjo Yogyakarta, setelah di wawancari rata-rata responden tidak diberikan motivasi dari keluarga dan orangorang terdekatnya karena mereka menggangap kalau penyakit ini sangat sering terjadi dan tidak harus ada perhatian khusus.

\section{METODE}

Penelitian ini merupakan merupakan jenis kuantitatif dengan metode korelasi yaitu penelitian mencari hubungan antar dua variabel, desain penelitian yang digunakan dalam penelitian ini adalah cross cestional. (Ircham Machfords, 2016; Sugiyono, 2011). Penelitian ini dilakukan di Yogyakarta tepatnya daerah Umbulharjo di Puskesmas Umbulharjo Yogyakarta pada tanggal 11 sampai 18 Juli 2019 dengan jumlah responden sebanyak 30 orang dari 46 populasi. Pengambilan sampel dengan metode total sampel dengan kriteria ; bersedia menjadi responden dan hadir untuk mengambil obat pada tanggal 11-18 Juli. Tiga puluh responden didapatkan karena 13 pasien sudah selesai menjalani pengobatan dan tiga pasien tidak datang berobat pada tanggal tersebut. Intrumen penelitian menggunakan intrumen baku terkait pengetahuan dan motivasi pengobatan pasien TB paru (Widianinggrum, 2017). 
Jurnal Kesehatan Karya Husada, Vol 9 No 1 Tahun 2021

PISSN 2337649X/EISSN 2655-8874

Alima Frida Merani, Bambang lskamto, Yafi Sabila Rosyad "Hubungan Tingkat Pengetahuan dengan Motivasi

Pasien Tuberkulosis Paru dalam Menjalani Pengobatan di Puskesmas Umbulharjo 1 Yogyakarta" (hal 64-73)

Analisis bivariat dilakukan terhadap dua variabel yang diduga berhubungan (Notoatmodjo, 2012). Untuk mencari hubungan dan menguji hipotesis antara dua variabel dengan skala ordinal dan ordinal digunakan Somer's D. Untuk mengetahui seberapa kuat hubungan antar variabel dengan melihat nilai koefesien korelasi dimana, jika nilainya 0.00 maka kekuatan hubungan tidak ada, 0.01-0.09 terdapat hubungan namun kurang berarti, 0.10-0.29 terdapat hubungan yang lemah, 0.30-0.49 terdapat hubungan yang sedang, 0.50-0.69 terdapat hubungan yang kuat,0.70-89 terdapat hubungan sangat kuat, dan $>0.89$ terdapat hubungan mendekati sempurna.

\section{HASIL DAN PEMBAHASAN}

\section{Karakteristik Responden}

Tabel I

Karakteristik responden $(\mathrm{n}=30)$

\begin{tabular}{ccccc}
\hline Karakteristik & & & $\%$ \\
\cline { 1 - 1 } Jenis Kelamin & & & \\
Laki-laki & & & 43,3 \\
Perempuan & & & 56,7 \\
\hline Usia & & & \\
Remaja (12-25) & & & 10,0 \\
Dewasa(26-45) & & & 40,0 \\
Masa lansia awal (46-55) & 8 & & 26,7 \\
Masa lansia akhir (56-65) & 6 & & 20,0 \\
Masa manula usia (>65) & & 1 & 3,3 \\
\hline Pendidikan & & & \\
Tidak sekolah & 1 & & 3,3 \\
Rendah (SD, SMP) & 10 & & 33,3 \\
Tinggi (SMA. D3, Sarjana) & 19 & & 63,3 \\
\hline
\end{tabular}

\begin{tabular}{ccc}
\hline Pekerjaan & & \\
Tidak Kerja & 2 & 6,7 \\
IRT & 12 & 40,0 \\
Wiraswasta & 13 & 43,3 \\
Mahasiswa & 2 & 6,7 \\
PNS & 1 & 3,3 \\
\hline
\end{tabular}

Berdasarkan hasil penelitian yang telah dilakukan peneliti, karakteristik responden berdasarkan jenis kelamin perempuan sebanyak 17 orang $(56,7 \%)$, dan laki-laki 13 orang $(43,3 \%)$. Perbedaan jenis kelamin juga mempengaruhi perkembangan penyakit dimana pada pada perempuan mempunyai penyakit yang lebih berat pada saat datang ke rumah sakit karena terlambar berobat. Hal ini bisa disebabkan karena adanya rasa malu dan aib yang lebih dirasakan pada perempuan dibanding lakilaki. Perempuan juga lebih sering mengalami kekhawatiran akan dikucilkan dari keluarga dan lingkungan akibat penyakitnya (Dwi et al 2012).

Utami, Galuh D (2013), dari hasil penelitiannya menemukan bahwa rata-rata usia pasien yang terkena TB Paru di domain umur dewasa (26-45 tahun). Menurut Nursalam (2009), Usia merupakan variabel penting dalam penelitian epidemologi salah satu hal yang mempengaruhi pengetahuan. Hal ini sama dengan frekuensi usia pasien Tb Paru dari penelitian ini paling panyak 
Jurnal Kesehatan Karya Husada, Vol 9 No 1 Tahun 2021

PISSN 2337649X/EISSN 2655-8874

Alima Frida Merani, Bambang lskamto, Yafi Sabila Rosyad "Hubungan Tingkat Pengetahuan dengan Motivasi

Pasien Tuberkulosis Paru dalam Menjalani Pengobatan di Puskesmas Umbulharjo 1 Yogyakarta" (hal 64-73)

dewasa awal (26-45 tahun) 8 orang $(40,0 \%)$

dibandingkan dengan usia lainnya.

Penelitian ini adalah pendidikan tinggi (SMA，D3， Sarjana) sebanyak 19 orang $(63,3 \%)$, Baiknya pengetahuan responden TB didukung dengan latar belakang pendidikan (Fitria \& Mutia, 2016), berdasarkan penelitian didapatkan sebagian besar responden memiliki tingkat pendidikan terakhir SMA, hingga perguruan tinggi, maka dapat disimpulkan bahwa mayoritas pendidikan responden dalam penelitian baik, hal ini didukung oleh Notoatmodjo (2014), yang mengatakan bahwa tingkat pengetahuan seseorang di pengaruhui oleh pendidikan, pada umumnya making tinggi pendidikan seseorang maka akan mudah dalam menerima informasi. Pekerjaan juga mempengaruhi pengetahuan, apabila Seseorang yang mempunyai sumber informasi yang lebih banyak dari pekerjaannya akan memperoleh pengetahuan yang lebih banyak akan memperoleh pengetahuan yang lebih luas, Frekuensi pekerjaan pasien TB Paru paling banyak wiraswasta sebanyak 13 orang $(43,3)$.

\section{Pengetahuan Tuberkulosis Paru pada pasien TB di Puskesmas Umbulharjo 1 Yogyakarta.}

Diketahui bahwa tingkat pengetahuan pasien TBC Paru terbanyak adalah tingkat pengetahuan baik sebanyak 16 orang $(53,3 \%)$. Teori lain yang mendukung adalah teori dari Nursalam, (2013) yang mengatakan bahwa pendidikan mempu menunjang kesehatan, meningkatkan kualitas hidup dan mempengaruhi sikap dan berperilaku seseorang.

Pengetahuan dipengaruhi oleh faktor pendidikan formal dan sangat erat hubungannya. Diharapkan dengan pendidikan yang tinggi maka akan semakin luas pengetahuannya. Tetapi orang yang berpendidikan rendah tidak mutlak berpengetahuan rendah pula. Peningkatan pengetahuan tidak mutlak diperoleh dari pendidikan formal saja, tetapi juga dapat diperoleh dari pendidikan non formal. Pengetahuan mengandung aspek positif dan aspek negatif. Kedua aspek ini akan menentukan sikap seseorang dalam berperilaku(Notoatmojo, 2014). Selain pendidikan formal pengetahuan juga dapat diperoleh dari pengalaman sendiri, pengetahuan seseorang dipengaruhi dari 
Jurnal Kesehatan Karya Husada, No 9 Vol 1 Tahun 2021

PISSN 2337649X/EISSN 2655-8874

Alima Frida Merani, Bambang lskamto, Yafi Sabila Rosyad "Hubungan Tingkat Pengetahuan dengan Motivasi

Pasien Tuberkulosis Paru dalam Menjalani Pengobatan di Puskesmas Umbulharjo 1 Yogyakarta" (hal 64-73)

berbagai faktor, dengan adanya pengetahuan

yang luas maka akan menjadikan seseorang memiliki sikap yang cenderung positif sehingga akan terbentuk perilaku yang baik pula pada seseorang atau subjek itu sendiri (Wawan \& Dewi, 2011). Humanawa (2015), bahwa pengetahuan seseorang didukung oleh latar belakang pendidikan, semakin lama seseorang menempung pendidikan maka akan semaking baik tingkat pengetahuannya. Penelitian Putra, (2011), menemukan bahwa tinggi rendahnya pendidikan sangat berpengaruh untuk mencegah penyakit TB Paru.

Penelitian ini menunjukan pengetahuan seseorang pengetahuan yang baik akan menunjang kesehatan seseorang, pengetahuan berpengaruh dengan penyakit yang diderita pasien TB Paru diharapkan pasien dapat menambah informasi terkait penyakit yang diderita.

\section{Motivasi Pasien Dalam Menjalani}

Pengobatan di Puskesmas Umbulharjo 1

Yogyakarta.

Dari hasil penelitian ini motivasi pasien sangan kuat di mana motivasi kuat di Puskesmas Umbulharjo 1 sebanyak 16 orang (53,3\%), Motivasi pasien TB di pengaruhi oleh faktor internal dan eksternal berupa keinginan untuk berobat, dukungan dari keluarga, masyarakat dan petugas kesehatan. Motivasi dikatakan baik bilamana seseorang mampu untuk mengendalikan dirinya menuju hal yang baik, Berdasarkan data yang diperoleh, sebagian besar responden memiliki motivasi yang baik dalam mencapai kesembuhan, dan sebagian lainnya memiliki motivasi cukup. Responden yang memiliki motivasi baik cenderung patut dalam minum obat (Nurwidji \& Fajri, (2013).

Suwarto (2010), pada proses motivasi, orang akan berusaha memenuhi berbagai macam kebutuhannya termasuk kebutuhan akan kesehatan. Oleh karena itu, seseorang akan memilih suatu tindakan untuk mencapai suatu tujuan. Adanya motivasi terhadap perilaku minum obat secara teratur, responden akan semakin meningkatkan perilaku minum obat teratur, dengan adanya motivasi yang positif bisa mengarah pada suatu perilaku yang positif pula. Sesuai dengan teori motivasi menyatakan bahwa motivasi sebagai dorongan dalam bertindak untuk mencapai tujuan tertentu (Mergeretha. 2012).

Menurut Santrock dalam Azwar (2010), Motivasi atau keinginan yang paling 
Jurnal Kesehatan Karya Husada, No 9 Vol 1 Tahun 2021

PISSN 2337649X/EISSN 2655-8874

Alima Frida Merani, Bambang lskamto, Yafi Sabila Rosyad "Hubungan Tingkat Pengetahuan dengan Motivasi

Pasien Tuberkulosis Paru dalam Menjalani Pengobatan di Puskesmas Umbulharjo 1 Yogyakarta" (hal 64-73)

kuat adalah dalam diri individu sendiri.

Motivasi individu ingin tetap

mempertahankan kesehatannya sangat

perpengaruh terhadap faktor-faktor yang

berhubungan dengan perilaku penderita

dalam kontrol penyakitnya. Penelitian ini

sejalan dengan Levi (2019), bahwa motivasi

yang kuat Sangat berpengaruh besar pada

pasien yang sedang menjalani pengobatan.

Tidak semua pasien TB Paru dapat menjalani pengobatan jangka panjang selama 6-8 bulan karena pasien cenderung mengalami kebosanan yang mengakibatkan penurunan motivasi. Ketidakpatuhan untuk berobat secara teratur bagi pasien TB Paru tetap menjadi hambatan untuk mencapai angka kesembuhan yang tinggi.

Penelitian ini menunjukan bahwa motivasi yang kuat sangat berpengaruh dengan pengobatan yang rutin, perlunya faktor motivasi intrinsik dan ekstrinsik dari pasien dan keluarga, lingkungan pasien yang akan sangat membantu pasien saat menjalani pengobatan.

Hubungan Pengetahuan dan Motivasi

Pasien Saat Menjalan Pengobatan di Puskesmas Umbulharjo 1 Yogyakarta.
Hasil penguji Hipotesis tingkat pengetahuan dengan motivasi pasien dalam menjalani pengobatan di Puskesmas Umbulharjo 1 Yogyakarta diperoleh nilai sebesar korelasi Somer's D sebesar .346 lebih kecil dari 0,005. Hasil ini menunjukan bahwa Ho ditolak Ha diterima sehingga penelitian ini menyatakan bahwa terdapat hubungan yang signifikan antara tingkat pengetahuan dengan motivasi pasien dalam menjalani pengobatan di Puskesmas Umbulharjo 1 Yogyakarta yang berarti semakin tingkat pengetahuan maka motivasi dalam menjalani pengobatan pada responden semakin baik pula.

Penelitian (Sutarno \& Gilang, 2012) tentang faktor-faktor yang mempengaruhi motivasi berobar penderita TBC secara umum ada dua yakni faktor internal dan faktor eksternal sedangka salah faktor internal yang sangat penting adalah tingkat pengetahuan TB Paru, saat melakukan pengobatan pengetahuan dan dukungan sosial sangatlah diperlukan untuk menunjang kesuksesan pasien TB Paru dalam melanjalani pengobatan.

Peneliti lain Pradika (2013), menemukan bahwa faktor yang menyebabkan pasien patuh atau rutin dalam 
Jurnal Kesehatan Karya Husada, No 9 Vol 1 Tahun 2021

PISSN 2337649X/EISSN 2655-8874

Alima Frida Merani, Bambang lskamto, Yafi Sabila Rosyad "Hubungan Tingkat Pengetahuan dengan Motivasi

Pasien Tuberkulosis Paru dalam Menjalani Pengobatan di Puskesmas Umbulharjo 1 Yogyakarta" (hal 64-73)

menjalani terapi pengobatan TB paru antara lain tingkat pengetahuan penderita yang menjelaskan bahwa tingkat pendidikan dapat mempengaruhi seseorang akan pola hidup terutama dalam memotivasi untuk sikap berperan serta dalam upaya kesehatan. Makin tinggi pendidikan seseorang makin mudah menerima informasi. Faktor yang sering ditemukan pada responden adalah faktor internal dari pasien yang meliputi pengetahuan pasien tentang tuberkulosis dan pengobatannya serta motivasi pasien (Setyowati, 2012). Hal ini sejalan dengan penelitian Prawati G. (2013), terdapat hubungan pengetahuan dengan motivasi dalam menjalani pengobatan TB. Motivasi merupakan karakteristik psikologis manusia yang memberikan kontribusi pada tingkat komitmen seseorang (Lestari, 2015). Disamping motivasi, pengetahuan juga merupakan domain yang penting dalam membentuk tindakan seseorang (overt behaviour). Proses kognitif meliputi ingatan, pikiran, persepsi, simbol-simbol penalaran dan pemecahan persoalan (Lestrari, 2015).

Dari hasil penelitian ini menunjukan bahwa ada hubungan yang sangat penting tentang pengetahuan dan motivasi, perawat dalam hal ini sangat berpegaruh pada pengetahuan dan motivasi di perlukan penyuluhan dan informasi terkait penyakit TB Paru pada pasien serta motivasi yang kuat dari petrugas kesehatan dan keluarga pasien serta pasien itu sendiri.

\section{SIMPULAN dan SARAN}

Berdasarkan hasil penelitian sebagian besar responden di Puskesmas Umbulharjo 1 Yogyakarta masuk dalam kategori pengetahuan baik dan memiliki motivasi $(53,3 \%)$ yang kuat dalam penjalani pengobatan TB. Akan tetapi, masih terdapatkan responden yang pengetahuannya dan motivasinya sedang-rendah (46.7\%). Petugas Puskesmas lebih giat lagi untuk memberikan edukasi kepada masyarakat binaan saat posyandu supaya informasi bisa tersebar secara luas sehingga pengetahuan masyarakat maupun keluarga terkait TB meningkat yang pada akhirnnya diharapkan akan menjadi sosial support bagi penderita TB untuk menjalani pengobatan. Peneliti menyarankan untuk penelitian selanjut melakukan intervensi psikoedukasi terkait pengetahuan pasien supaya motivasi menjalani pengobatannya menjadi semakin baik.

\section{DAFTAR PUSTAKA}


Jurnal Kesehatan Karya Husada, No 9 Vol 1 Tahun 2021

PISSN 2337649X/EISSN 2655-8874

Alima Frida Merani, Bambang lskamto, Yafi Sabila Rosyad "Hubungan Tingkat Pengetahuan dengan Motivasi

Pasien Tuberkulosis Paru dalam Menjalani Pengobatan di Puskesmas Umbulharjo 1 Yogyakarta” (hal 64-73)

Azwar, S. 2010. Sikap Manusia Teori dan

Kesehatan. Nuha Medika:

Pengukurannya edisi 1.

Yogyakarta

Yogyakarta: Pustaka Pelajar.

Dinkes DIY. (2016). Data Kesehatan

Tuberkulosis Paru.

Dinkes DIY. (2017). Data Kesehatan

Tuberkulosis Paru.

Galuh Prabawati Utami, - (2013). Hubungan

Tingkat Pengetahuan Tentang TB

Paru dengan Motivasi Pasien

dalam Menjalani Pengobatan di

Poli Paru Rumah Sakit Panti

Rapih Yogyakarta.Skripsi,

STIKES Jenderal Achmad Yani

Yogyakarta

Kholifatul Ma'arif Zainul Firdaus

(2012).Pengaruh Pengawas

Menelan Obat (PMO) Terhadap

Keberhasilan Pengobatan TB

diwilayah Kerja Puskesmas Baki

Sukoharjo. Skripsi.Universitas

Muhammadiyah Surakarta.

Kemenkes RI. (2015). Data Kesehatan

Tuberkulosis Paru.

Kemenkes RI. (2018). Upaya Pengendalian Tuberkulosis Paru.

Lestari Titik. (2015). Kumpulan Teori Untuk

Kajian PustakaPenelitian

Levi Sari Tina (2019).Hubungan Motivasi Kesembuhan dengan Kepatuhan pada Penderita TB Paru. Jurnal Kesehatan. 3(1). Retrieved from https://jurnal.stikesganeshahusada .ac.id/index.php/juke/article/view/ 125

Machfoedz I. (2015). Bio Statistik, Yogyakarta: Fitramaya

Mergeretha (2012). Hubungan Motivasi Kesembuhan

Dengan

Kepatuhan Minum Obat Pada

Pasien Tb Paru Dewasa Eka Hospital BSD.

Nursalam.(2009). Prinsipdan Penerapan Metodologi Penelitian Ilmu Keperawatan. Jakarta: SalembaMedika.

Nurwidji \& Fajri, (2013). Hubungan Motivasi Kesembuhan Dengan Kepatuhan Pelaksanaan Pengobatan Pada Pasien Tb Paru Di Wilaya Kerja Paru Mojosari Mojokerto.

Notoatmodjo. (2012), Metode Peneletian Kesehatan. Jakarta: PT Rineka Cipta 
Jurnal Kesehatan Karya Husada, No 9 Vol 1 Tahun 2021

PISSN 2337649X/EISSN 2655-8874

Alima Frida Merani, Bambang lskamto, Yafi Sabila Rosyad "Hubungan Tingkat Pengetahuan dengan Motivasi

Pasien Tuberkulosis Paru dalam Menjalani Pengobatan di Puskesmas Umbulharjo 1 Yogyakarta” (hal 64-73)

Pradita B. (2013). Hubungan antara Tingkat

Pengetahuan dengan
Kepatuhan Penggunaan Obat
Antituberkulosis oleh Pasien
Tuberkulosis Paru di Instalasi
Rawat Jalan Balai Besar
Kesehatan Paru Masyarakat
Surakarta.
Universitas
Surakarta.

Putra NR. 2011. Hubungan Perilaku dan Kondisi Sanitasi Rumah dengan Kejadian TB Paru di Kota Solok. Skripsi. Sumatra Barat: Universita Andalas Padang.

Puspita A. (2016). Faktor-Faktor Yang Berhubungan Dengan Motivasi Pasien Untuk Menjalani Terapi Hemodialisa Di Rsud Dr. Soedirman. Gombong: Stikes Muhamadiyah Gombong.

Setyowati, DRD. 2012. Evaluasi Tingkat Kepatuhan Penggunaan Obat Tuberkulosis Di Puskesmas Kabupaten Sukoharjo. Fakultas farmasi, UMS.

Sutarno, Gilang A. U. (2012) Faktor-Faktor Yang Memengaruhi Motivasi Berobat Penderita
Tuberkulosis. Pekalongan:

Stikes Statistik

Utami P.G. (2014). Hubungan tingkat pengetahuan tentang tb paru dengan motivasi pasien dalam menjalani terapipengobatan di poli paru rumah sakit panti rapih yogyakarta. Yogyakarta: Universita Jendral Achmad Yani Yogyakarta

Wawan A, Dewi M. (2019). Teori \& Pengukuran Pengetahuan, Sikap Dan Perilaku Manusia. Yogyakarta: Nuha Medika.

Widianingtrum, Tri Retno. (2017).

Hubungan Pengetahuan dan Motivasi dengan Kepatuhan Minum Obat Anti tuberkolosis pada Pasien TB di Wilayah Kerja Puskesmas Perak Timur Surabaya. Surabaya: Unair WHO. (2015). Data tentang Tuberkulosis Paru. 